\title{
POTENSI ZEOLIT ALAM GUNUNG KIDUL TERAKTIVASI SEBAGAI MEDIA ADSORBEN PEWARNA TEKSTIL
}

\author{
THE POTENTIALITY OF ACTIVATED NATURAL ZEOLITE FROM GUNUNG \\ KIDUL AS ADSORBEN TO TEXTILE DYES
}

\author{
Wulan Safrihatini Atikah \\ Politeknik STTT Bandung, Jalan Jakarta No.31 Bandung 40272 \\ E-mail: wulansafrihatini@yahoo.co.id
}

Tanggal diterima: 7 Maret 2017, direvisi: 4 Oktober 2017, disetujui terbit: 2 November 2017

\begin{abstract}
ABSTRAK
Zeolit alam merupakan batuan mineral anorganik yang banyak terdapat di Indonesia. Zeolit alam adalah bahan berpori dengan sifat fisikokimia yang baik, seperti kapasitas tukar kation yang tinggi, selektivitas kation dan volume pori besar. Penggunaan zeolit telah berkembang dalam berbagai bidang industri, pengolahan air dan pengolahan air limbah. Sifat dari zeolit alam banyak ditentukan oleh sumber zeolit tersebut berasal. Dalam penggunaannya, zeolit alam harus melalui proses aktivasi yang bisa dilakukan secara fisika ataupun kimia. Pada percobaan ini akan dilakukan karakterisasi pada zeolit alam dari Gunung Kidul. Zeolit alam disiapkan dengan ukuran 150 mesh. Aktivasi dilakukan dengan menggunakan metode kimia dengan pengasaman menggunakan larutan $\mathrm{HCl} 5 \mathrm{M}$ dan metode fisika yaitu kalsinasi pada suhu $150^{\circ} \mathrm{C}$. Zeolit alam hasil aktivasi dievaluasi karakteristiknya menggunakan XRD, KTK dan BET. Berdasarkan hasil XRD, zeolit alam Gunung Kidul teraktivasi secara kimia akan menghasilkan senyawa modernit dimana sangat cocok bila dijadikan sebagai media adsorben. Hasil uji KTK dan BET menunjukkan hasil optimum pada proses aktivasi zeolite secara kimia. Dilakukan pula uji kemampuan adsorben dalam menyisihkan pewarna tekstil yang diuji pada beberapa variasi $\mathrm{pH}$. Hasil karakterisasi dan pengujian dapat dijadikan acuan dalam mengukur potensi Zeolit Alam teraktivasi yang berasal dari Gunung Kidul untuk dapat diaplikasikan sebagai media adsorben dalam pengolahan limbah pewarna tekstil.
\end{abstract}

Kata kunci : adsorben, Gunung Kidul, kalsinasi, pewarna, zeolit

\begin{abstract}
Natural zeolite is a mineral inorganic rock in Indonesia. Natural zeolite porous materials is with the nature of the good physicochemistry, such as cation exchange capacity cation selectivity, high volume and large pores. Use of zeolite has developed in various fields of industry, water treatment and wastewater treatment. The nature of natural zeolite a lot is determined by the source of the zeolite is derived. In its use, natural zeolite has to go through the activation process can be done in physics or chemistry. This experiment will be conducted on the characterization of natural zeolites of Gunung Kidul. Natural zeolite prepared with a size of 150 mesh. Activation is done by using chemical methods with $5 \mathrm{~m} \mathrm{HCl}$ solution using the acidification and physical methods namely kalsinasi at $150^{\circ} \mathrm{C}$. Activated natural zeolite was characterized by XRD, CEC and BET. Based on the results of XRD, natural zeolite chemically activated of Gunung Kidul will produce compound modernit which is perfect when used as adsorbent. The test results of the CEC and BET shows the optimum results on chemically zeolite activation process. It is also carried out to measure the capability of adsorbents in the textile dyes which tested on some variation of the $\mathrm{pH}$. The results of the characterization and testing is expected will be refference in measuring the potential use of activated natural zeolite originated from Gunung Kidul to be applied as adsorbents in wastewater treatment of textile dye.
\end{abstract}

Keywords: adsorbent, calcination, Gunung Kidul, textile dyes, zeolite 


\section{PENDAHULUAN}

Zeolit merupakan kristal alumina silikat terhidrasi yang mengandung kation alkali atau alkali tanah berbentuk kerangka tiga dimensi, bersifat asam dan mempunyai pori yang berukuran molekul. Rumus molekul empiris zeolit adalah $\mathrm{M}_{2 \mathrm{n}}\left(\mathrm{Al}_{2} \mathrm{O}_{3} \cdot \mathrm{ySiO}_{2}\right) \mathrm{wH}_{2} \mathrm{O}$ dimana $\mathrm{M}=$ kation alkali tanah atau alkali, $\mathrm{n}=$ valensi logam alkali dan $\mathrm{x}, \mathrm{y}=$ bilangan tertentu. ${ }^{1}$ Zeolit terdiri dari 3 komponen yaitu kation yang dapat dipertukarkan, kerangka alumina silikat dan kandungan air. Kandungan air berubah-ubah tergantung dari sifat kation-kation yang ditukar dan kondisi kristalisasi. Air dan kation yang ada di dalam rongga zeolit dapat disubstitusikan dengan molekul lain. Zeolit merupakan mineral berpori dan memiliki sifat yang sama dengan mineral silika lainnya. Jika terdapat beberapa interaksi molekul dengan zeolit. Mekanisme interaksi molekul yang terjadi bisa secara penyerapan fisika (gaya Van der Waals), penyerapan kimia (gaya elektrostatik), ikatan hidrogen dan pembentukan kompleks koordinasi. Efektivitas penyerapan bergantung pada sifat spesies yang diserap, kemampuan pertukaran ion, keasaman padatan zeolit dan kelembaban sistem. Zeolit dengan rongga-rongga molekulnya mempunyai gugus aktif di dalam saluran antar kristal sehingga dapat berlaku sebagai pengemban katalis.

Zeolit mempunyai kegunaan yang luas dalam bidang agrikultura, holtikultura, rumah tangga, industri, pengolahan air dan pengolahan air limbah. $^{2}$ Kaitannya dalam bidang industri dan pengolahan air dan limbah, zeolit digunakan sebagai adsorben, pengemban katalis dan penghilang logam berat. Contoh aplikasi di bidang tekstil adalah mengatasi permasalahan limbah zat warna tekstil, metode yang banyak digunakan adalah metode adsorpsi, karena penggunaan adsorben relatif sederhana dan mudah diregenerasi ${ }^{5}$. Metode adsorpsi juga relatif murah karena berbagai adsorben dapat diperoleh dengan mudah misalnya karbon aktif, lumpur dan zeolit alam. ${ }^{\mathbf{1}}$ Zeolit alam telah dikenal sejak lama sebagai adsorben yang efektif untuk berbagai peruntukan termasuk untuk pengolahan limbah. Namun demikian, bahan ini memiliki sejumlah kelemahan antara lain mengandung banyak pengotor, komposisi yang beragam serta kristalinitasnya kurang baik. Keberhasilan teknik aktivasi akan sangat menentukan keberhasilan zeolit dalam aplikasinya dan akan pada perkembangan adsorben efisien yang banyak digunakan sebagai adsorben untuk adsorpsi ion dan organik dalam pengolahan air limbah.

Aplikasi zeolit alam untuk pengolahan air dan air limbah sudah banyak diaplikasikan dan masih berpotensi untuk dilakukan pengembangan dalam proses pengolahan lingkungan. Kegunaan zeolit didasarkan atas kemampuannya melakukan 18 pertukaran kation adsorpsi dan katalisator. Zeolit memiliki bentuk kristal yang sangat teratur dengan rongga yang saling berhubungan ke segala arah yang menyebabkan luas permukaan zeolit sangat besar sehingga sangat baik digunakan sebagai adsorben. ${ }^{11}$ Saat ini mineral alam seperti zeolit banyak dimanfaatkan sebagai bahan proses dalam industri. khususnya sebagai penyerap alternatif pada pengolahan limbah dan sebagai penjernih pada proses dekolorisasi. Faktor penting yang menjadikan zeolit diambil untuk bahan penyerap karena selain murah, zeolit mudah didapatkan di wilayah Indonesia. Berdasarkan penelitian yang dilakukan sebelumnya, zeolit asal Wonosari Gunung Kidul merupakan jenis modernit dan klipnoptilotit dengan kandungan $\mathrm{SiO}_{2}$ sebesar $65,56 \%$ dan $\mathrm{Al}_{2} \mathrm{O}_{3}$ sebesar $11,04 \% .{ }^{4}$ Penelitian lain menyatakan bahwa zeolit dari Gunung Kidul memiliki kadar senyawa silikat cukup tinggi (mengandung Ca-silikat pada kisaran 45,65 \% sampai 52,75 \%), sehingga diduga memiliki kemampuan sorpsi yang tinggi. ${ }^{5}$

Zeolit agar dapat diaplikasikan sesuai fungsinya, diperlukan proses tertentu agar diperoleh zeolite denagn kualitas yang baik. Cara yang digunakan untuk menaikkan kualitas zeolit biasanya dilakukan melalui proses pengolahan dan aktivasi, baik dengan cara pemanasan, penambahan asam atau basa, maupun pelapisan dengan senyawa kimia tertentu. Aktivasi secara fisis berupa pemanasan zeolit dengan tujuan untuk menguapkan air yang terperangkap dalam pori-pori kristal zeolit, sehingga luas permukaan pori-pori bertambah. Aktivasi dengan pemanasan ini sering juga dikenal dengan kalsinasi. Aktivasi secara kimiawi dilakukan dengan asam atau basa, dengan tujuan untuk membersihkan permukaan pori, membuang senyawa pengotor, dan mengatur kembali letak atom yang dapat dipertukarkan. Pereaksi kimia ditambahkan pada zeolit dalam jangka waktu tertentu. Zeolit kemudian dicuci sampai netral dan kemudian dikeringkan. Pengaktifan dengan asam mineral akan melarutkan logam alkali seperti $\mathrm{Ca}^{2+}$, $\mathrm{K}^{+}, \mathrm{Na}^{+}$dan $\mathrm{Mg}^{+}$yang menutup sebagian rongga pori dan pengaktifan dengan $\mathrm{H}^{+}$dalam ruang interlaminer sehingga zeolit lebih porous dan permukaan lebih aktif. Pada penelitian ini akan dilakukan kajian aktivasi zeolit menggunakan kalsinasi dan pertukaran asam. Aktivasi secara kimia dapat dilakukan dengan menggunakan larutan asam klorida atau asam sulfat yang bertujuan untuk membersihkan permukaan pori, membuang senyawa pengganggu dan menata kembali letak atom yang dapat dipertukarkan. ${ }^{3}$

Terdapat banyak jenis zeolit alam yang teridentifikasi di dunia. Jenis yang banyak ditemukan antara lain klinoptilolit, mordenit, phillipsit, chabazite, stilbite, analsim dan laumontite sedangkan offretite, paulingite, barrerite dan 
mazzite, lebih jarang. ${ }^{7}$ Di antara zeolit, klinoptilolit adalah zeolit alam paling berlimpah dan banyak digunakan dalam dunia. Penentuan jenis zeolite dapat dilakukan melalui analisis struktur mikro dari mineral dalam batuan. Karakterisasi mineral zeolit dapat dilakukan dengan penggunaan suatu mikroskop optik dan alat penunjangnya. Analisa dengan menggunakan SEM, EDS, XRF, XRD akan sangat membantu penentuan kandungan dan jenis mineral yang dikandung dalam suatu zeolit. ${ }^{13}$ Proses karakterisasi akan memberikan informasi signifikan untuk penentuan aplikasi yang cocok bagi jenis zeolit yang ditentukan. Zeolit dapat diaplikasikan sebagai suatu penukar kation, karena zeolit mengandung berbagai unsur logam yang dapat dipertukarkan dengan logam lain yang diinginkan. Zeolit memiliki struktur tiga dimensi dan mempunyai pori-pori atau ruang-ruang yang dapat diisi oleh kation lain ataupun molekul air. Karakter struktur kisi kristal berongga dalam zeolit berfungsi mengikat molekul air dan ion-ion logam. Ion-ion logam dan molekul air tersebut bebas bergerak dalam kerangka zeolit menyebabkan zeolit dapat digunakan untuk pertukaran ion tanpa mengalami perubahan dalam struktur kristal zeolit. 13 Unit dasar pembentuk zeolit adalah $\mathrm{SiO}_{4}$ dan $\mathrm{AlO}_{4}$ yang mempunyai bentuk tetrahedral. Unit-unit tersebut saling berikatan membentuk jaringan anionik dalam tiga dimensi. Masing-masing atom oksigen terbagi diantara atom $\mathrm{Si}$ dan $\mathrm{Al}$, oleh karena itu perbandingan $(\mathrm{Al}, \mathrm{Si}): \mathrm{O}=1: 2$. Perbandingan Al:Si dalam suatu zeolit akan menentukan kerapatan muatan di dalam kristal. Jika perbandingan besar maka dalam struktur kerapatan muatan akan tinggi, molekulnya polar dan kemampuan untuk mengikat molekul besar akan bertambah, dengan kata lain kapasitas tukarnya tinggi. ${ }^{2}$ Zeolit mempunyai struktur berongga dan biasanya diisi oleh air dan kation yang dapat dipertukarkan dan memiliki ukuran pori tertentu.

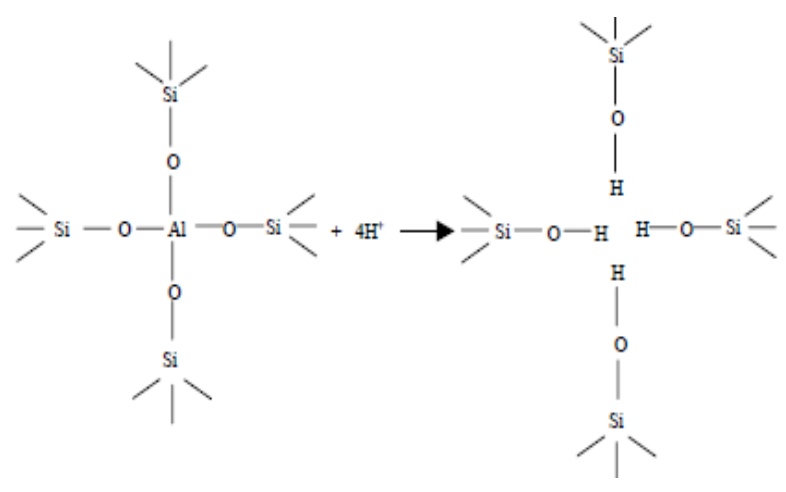

Gambar 1. Reaksi Aktivasi Zeolit dengan Asam Mineral
Banyak penelitian yang telah dilakukan untuk mengetahui kemampuan adsorpsi mineral tersebut, baik untuk mengadsorpsi logam maupun untuk mengadsorpsi senyawa organik. Penelitian yang telah dilakukan diantaranya oleh Endang (2008), ditemukan bahwa proses aktivasi zeolit efektif dengan menggunakan larutan pengaktif asam kuat. $^{5}$

Kuantitas $\mathrm{H}^{+}$akan sebanding dengan jumlah $\mathrm{H}^{+}$permukaan dan sebanding pula dengan kemampuan adsorpsinya. Batuan alam zeolit karakteristiknya sangat dipengaruhi oleh sumber batuan tersebut berasal dan akan mempengaruhi terhadap kondisi proses dan hasilnya. Penelitian terbaru yang dilakukan oleh Farhad menunjukkan zeolit yang berasal dari Iran yang digunakan sebagai media adsorben untuk senyawa amonium dilakukan pada $\mathrm{pH} 7$ dengan waktu kontak 30 menit. ${ }^{8}$ Penelitian yang dilakukan oleh Graeme (2016) menunjukkan sifat zeolit sebagai media dengan memiliki kemampuan kapasitas tukar kation. 9 Pada penelitian yang dilakukan sebelumnya, zeolit alam Lampung teraktivasi asam terbukti efektif sebagai media adsorben logam kromium selama 3 jam dengan nilai mencapai 99,725\% dengan model isoterm Freudlich dan nilai kapasitas $\mathrm{Kf}=0,044463 \mathrm{mmol} / \mathrm{gram}^{3}$. Penelitian lain yang pernah dilakukan pula oleh Nassidiniyah (2016), dimana melakukan penelitian terhadap kemampuan zeolit termodifikasi terhadap zat warna malasit green. Pada aplikasinya menggunakan zeolit alam ditemukan waktu terbaik untuk proses adsorpsi diperoleh di menit ke-50 dengan daya adsorpsi 9,7944 mg/g. ${ }^{\mathbf{1 0}}$ Sifat dari zeolit alam sangat bergantung kepada daerah asalnya. Untuk itulah, pada penelitian ini akan dilakukan kajian mengenai karakterisasi dari zeolit alam dari Desa Sidomulyo Gunung Kidul teraktivasi secara fisika ataupun kimia.

\section{METODE \\ Bahan}

Bahan yang diperlukan dalam penelitian ini adalah zeolit alam Gunung Kidul dari Desa Sidomulyo, aquadest, $\mathrm{HCl} 5 \mathrm{M}$, zat warna reaktif Chloranil Yellow H-E4R.

\section{Peralatan}

Peralatan yang digunakan di laboratorium meliputi ayakan 150 mesh, kertas saring, oven, tanur,stirrer, magnetic stirrer,neraca analitik, beaker glass,labu takar, pipet ukur, pipet volume, pipet tetes, bola hisap, kaca arloji, spatula, erlen meyer, corong kaca. 


\section{Pengujian}

Untuk mengukur karakteristik dari zeolit alam yang teraktivasi dilakukan pengujian XRD, XRF, BET dan KTK

\section{Tahap Persiapan}

Tahap Persiapan Zeolit Alam Gunung Kidul ${ }^{5}$

Zeolit alam yang berbentuk granular dan berwarna hijau kebiruan ditumbuk dengan mortar, kemudian diayak dengan menggunakan alat penyaring untuk mendapatkan zeolit alam yang berukuran 150 mesh.

\section{Pengaktifan fisika dengan pemanasan ${ }^{5}$}

Zeolit bubuk selanjutnya dimasukkan ke dalam cawan porselain, dipanaskan dalam tanur pada suhu $150^{\circ} \mathrm{C}$ selama 60 menit, didiamkan dalam tanur sampai suhu kamar dan ditampung dalam wadah tertutup rapat. Zeolit hasil pengaktifan fisika ini dikeringkan pada suhu udara, setelah kering diayak sehingga diperoleh zeolit hasil pengaktifan fisika dengan ukuran butir 150 mesh.

\section{Pengaktifan kimia $\mathrm{HCl}^{1}$}

Zeolit ukuran butir 150 mesh sebanyak 500 gram dimasukkan ke dalam gelas beker volume $2000 \mathrm{~mL}$ yang telah berisi larutan $\mathrm{HCl} 5 \mathrm{M}$ pada suhu kamar sampai seluruh butiran zeolit terendam. Selanjutnya diaduk pada kecepatan pengadukan 50 rpm selama 30 menit menggunakan perangkat magnetik stirrer. Hasilnya disaring menggunakan kerts saring, kemudian padatan dalam kertas saring dimasukkan ke dalam gelas beker $2000 \mathrm{~mL}$. Selanjutnya padatan dalam beker gelas dicuci dengan akuades yaitu dengan cara ditambahkan akuades $1000 \mathrm{~mL}$, diaduk lambat $50 \mathrm{rpm}$ selama 10 menit, disaring dan diukur $\mathrm{pH}$ filtratnya. Pencucian terhadap padatan diulang dengan cara yang sama sampai diperoleh $\mathrm{pH}$ filtrat $=7,0$.

Padatan yang diperoleh dipindahkan ke dalam beker gelas $2000 \mathrm{~mL}$ untuk dicuci dengan ethanol teknis sebanyak $500 \mathrm{ml}$ dengan cara diaduk (30 rpm) selama 60 menit, disaring menggunakan kertas saring. Padatan dalam kertas saring dipindahkan ke dalarn cawan porselain, dikeringkan menggunakan oven sampai diperoleh berat padatan yang tetap. Padatan zeolit hasil pengaktifan digerus dan diayak dengan ayakan ukuran 150 mesh, hasilnya disimpan dalam eksikator.

\section{Tahap karakterisasi zeolit Gunung Kidul}

Zeolit alam Gunung Kidul akan dibandingkan berdasarkan cara aktivasinya. Karakterisasi zeolit Gunung Kidul teraktivasi dilakukan dengan analisa volume pori dan analisa luas permukaan menggunakan metode BET, XRD, XRF dan kemampuan kapasitas tukar kationnya dilakukan dengan uji KTK.

\section{HASIL DAN PEMBAHASAN \\ Hasil ujiXRD}

Berdasarkan hasil pengujian menggunakan XRD diperoleh data seperti ditunjukkan pada Tabel 1.

Tabel 1. Hasil Uji XRD pada Zeolit

\begin{tabular}{lc}
\hline \multicolumn{1}{c}{ Jenis Zeolit } & Komposisi Mineral \\
\hline Zeolit Alam dengan & Mordenit, \\
Aktivasi Fisika & Klinoptilolit \\
$\begin{array}{l}\text { Zeolit Alam dengan } \\
\text { Aktivasi Kimia }\end{array}$ & Mordenit \\
\hline
\end{tabular}

Mordenit merupakan salah satu anggota group zeolit yang penyebarannya di alam cukup banyak. Mordenit termasuk kelompok zeolit mikropori dengan struktur kristal orthorombik dengan kanal-kanal atau saluran-saluran terbuka yang memungkinkan air dan ion-ion berukuran besar keluar dan masuk saluran-saluran tersebut. Ukuran saluran-saluran tersebut beragam sehingga mordenit dapat berfungsi sebagai penyaring molekular dan adsorben. Selain mordenit, klinoptilolit merupakan anggota group zeolit yang juga banyak dijumpai di alam Klinoptilolit merupakan kristal monoklinik, serta memiliki resistensi panas yang tinggi. Berdasarkan hasil pengujian XRD diperoleh bahwa dengan aktivasi kimia akan menghasilkan struktur mineral modernit. Berdasarkan sifatnya sehingga zeolit dengan aktivasi kimia ini berpotensi sebagai media adsorben.

Kandungan utama mineral dalam zeolit ini adalah (Ca, $\left.\mathrm{Na}_{2}, \mathrm{~K}_{2}\right) . \quad \mathrm{Al}_{2} \mathrm{Si}_{10} \mathrm{O}_{24}$ sedangkan pengotornya adalah kuarsa. Sifat mineral zeolit alam Gunung kidul ini sama halnya dengan zeolit alam Malang memiliki struktur mordenit, ${ }^{\mathbf{1 0}}$ sedangkan hasil penelitian yang dilakukan oleh Lestari, terhadap zeolit alam Malang memiliki sifat mineral menunjukkan hasil yang berbeda yaitu hasil XRD menunjukkan bahwa zeolit alam Malang memiliki struktur mordenit yang tercampur dengan klinoptilolit. ${ }^{7}$ Sifat itu sama dengan zeolit Wonosari Gunung Kidul yang mengandung kristal mordenit dan klinoptilolit.

\section{Hasil uji XRF}

Berdasarkan hasil analisis dengan XRF dapat diketahui bahwa senyawa alumina dan silika merupakan komponen penyusun zeolit yang utama. Unsur - unsur yang terdapat dalam zeolit Alam Desa Sidomulyo Gunung Kidul dapat dilihat pada Tabel 2. 
Tabel 2. Komposisi Unsur Zeolit Alam Asal Desa Sidomulyo Gunung Kidul

\begin{tabular}{ccc}
\hline \multirow{2}{*}{$\begin{array}{c}\text { Unsur } \\
\text { dalam } \\
\text { bentuk } \\
\text { Oksida }\end{array}$} & \multicolumn{2}{c}{ Konsentrasi (\%) } \\
\cline { 2 - 3 } & $\begin{array}{c}\text { Sebelum } \\
\text { Aktivasi }\end{array}$ & $\begin{array}{c}\text { Sesudah } \\
\text { aktivasi }\end{array}$ \\
\hline $\mathrm{SiO}_{2}$ & 73,20 & 68,91 \\
$\mathrm{Al}_{2} \mathrm{O}_{3}$ & 12,85 & 12,38 \\
$\mathrm{Fe}_{2} \mathrm{O}_{3}$ & - & 1,55 \\
$\mathrm{CaO}$ & 3,96 & 2,70 \\
$\mathrm{MgO}$ & 0,73 & 0,38 \\
$\mathrm{Na} \mathrm{O}$ & 1,35 & 0,65 \\
$\mathrm{~K}_{2} \mathrm{O}$ & 0,76 & 0,85 \\
\hline
\end{tabular}

Perbandingan Si dan Al dari zeolit menggambarkan fungsi kapasitas tukar kationnya. Data hasil analisis XRF menunjukkan bahwa perbandingan persentase antara $\mathrm{SiO}_{2}$ dan $\mathrm{Al}_{2} \mathrm{O}_{3}$ relatif lebih kecil yaitu 5,56. Perbandingan ini secara teoritis menunjukkan bahwa kapasitas kationnya relatif besar. Hasil ini diperoleh pada zeolit alam yang telah diproses menggunaan asam. $\mathrm{HCl}$ bereaksi dengan zeolit sehingga menyebabkan terekstraknya $\mathrm{Al}$ dari zeolit. Hal ini mengakibatkan turunnya kandungan $\mathrm{Al}$ dalam zeolit sehingga rasio mol Si/Al naik. Kandungan logam seperti Ca dan Mg pada zeolit mengalami penurunan setelah perlakuan karena terjadinya pertukaran ion antara kation-kation dari zeolit dengan proton dari $\mathrm{HCl}$.

Hasil analisis menggunakan XRF menunjukkan bahwa proses perlakuan asam ( $\mathrm{HCl} 5$ M) pada katalis menyebabkan terjadinya penurunan kandungan logam $\mathrm{Ca}$ dan $\mathrm{Mg}$ pada zeolit dan peningkatan keasaman zeolit. Aktivasi secara kimia dilakukan dengan pengasaman dengan tujuan agar terjadi dealuminasi. Tujuan dealuminasi adalah untuk mengoptimalkan kandungan aluminium dalam zeolit, sehingga zeolit menjadi lebih stabil pada temperatur tinggi, mengontrol keasaman dan selektivitas zeolit. Dealuminasi adalah proses perusakan struktur kerangka zeolit dimana terjadi pemutusan $\mathrm{Al}$ dalam kerangka (Al framework) menjadi Al luar kerangka (Al non-framework) akibatnya rasio $\mathrm{Si} / \mathrm{Al}$ akan menjadi semakin meningkat.

\section{Hasil uji BET}

Perlakuan asam juga dapat menyebabkan terjadinya peningkatan rasio Si/Al. Setelah perlakuan asam, volume dan luas permukaan mengalami peningkatan. Hasil uji luas permukaan dan pori dilakukan dengan Metoda BET dapat dilihat pada Tabel 3. Setelah perlakuan dengan asam luas permukaan spesifik, rerata jejari pori dan volume total pori katalis mengalami peningkatan.
Peningkatan ini lebih disebabkan karena terjadinya pembukaan pori zeolit alam yang semula tertutupi oleh pengotor melalui reaksi dengan $\mathrm{HCl}$.

Luas permukaan spesifik zeolit alam mengalami kenaikan yang sangat signifikan setelah perlakuan dengan $\mathrm{HCl} 5 \mathrm{M}$. Peningkatan luas permukaan spesifik zeolit juga berpengaruh pada peningkatan volume total pori. Luas permukaan spesifik zeolit meningkat karena $\mathrm{HCl} 5 \mathrm{M}$ dapat melarutkan pengotor baik organik maupun anorganik yang bersifat menutupi pori, sehingga pori-pori zeolit menjadi terbuka dan permukaannya menjadi lebih luas. Perbandingan luas permukaan dan volume pori dengan dua metode aktivasi dapat dilihat pada Tabel 3.

Tabel 3 Perbandingan Hasil Uji BET

\begin{tabular}{ccc}
\hline Aktivasi & $\begin{array}{c}\text { Luas } \\
\text { Permukaan }\end{array}$ & Volume pori \\
\hline Fisika & $31.857 \mathrm{~m}^{2} / \mathrm{g}$ & $0.124 \mathrm{cc} / \mathrm{g}$ \\
Kimia & $44.054 \mathrm{~m}^{2} / \mathrm{g}$ & $0.133 \mathrm{cc} / \mathrm{g}$ \\
\hline
\end{tabular}

Tabel 3 menunjukkan bahwa proses aktivasi kimia memberikan hasil yang lebih baik bila digunakan sebagai media adsorpsi.

\section{Hasil uji KTK}

Kemampuan zeolit alam Gunung kidul dengan variasi proses aktivasi bila dimanfaatkan sebagai penukar ion dapat dilihat pada Tabel 4 .

Tabel 4. Nilai KTK dengan Variasi Aktivasi Zeolit Alam Gunung Kidul

\begin{tabular}{cc}
\hline Jenis asal zeolit & KTK (meq/100 g) \\
\hline Aktivasi Kimia & 29,42 \\
Aktivasi Fisika & 12,99 \\
\hline
\end{tabular}

Kapasitas tukar kation adalah banyaknya kation yang dapat ditukarkan dalam satuan berat equivalen tiap satuan berat mineral dari bahan galian alam. Pada percobaan ini selain diukur nilai KTK total, juga dianalisis nilai kapasitas tukar kation yang ditimbulkan karena adanya logamlogam alkali yang bersifat kationik (Ca, Mg, Na dan K). Kemampuan zeolit sebagai sorben didukung oleh adanya kandungan senyawa alumunium silikat di dalamnya yang memiliki struktur kerangka tiga dimensi di dalam zeolit dengan rongga di dalamnya terisi ion-ion logam biasanya logam alkali tanah (Na, K, Mg, Ca dan Fe) dan molekul air yang dapat bergerak bebas.

Untuk mempermudah terjadinya proses pertukaran kation - kation, padatan zeolit dibuat homogen terlebih dahulu dengan proses pengaktifan 
yaitu dengan menambah asam atau garam tertentu, atau dengan pemanasan. Pengaktifan mineral lokal dapat dilakukan dengan menambahkan larutan asam atau garam (sulfat, khlorida, nitrat). Langkah ini bertujuan untuk membersihkan permukaan poripori mineral, membuang senyawa-senyawa pengotor dan reposisi letak atom dalam pori yang dapat dipertukarkan dengan memperbesar kemungkinan naiknya pergerakan logam-logam alkali tanah yang ada di dalamnya.

Nilai KTK total dari zeolit jenis klinoptilolit pada umumnya antara $(1,5-2,0)$ meq/g dan KTK total dari bentonit bervariasi dari $(0,4-1,2) \mathrm{meq} / \mathrm{g} .{ }^{5}$ Logam-logam alkali yang bersifat kationik tersebut secara terpisah mampu menaikkan nilai KTK total dari sorben zeolit tergantung kemudahan logamlogam alkali tersebut bergerak dalam sistem saluran-saluran kerangka zeolit. Kation-kation tersebut mempunyai mobilitas yang tinggi, sehingga dapat memudahkan proses pertukaran ion.

Data bahwa nilai kapasitas tukar kation zeolit dapat ditingkatkan dengan cara pengaktifan kimia, dalam percobaan ini digunakan larutan aktivan $\mathrm{HCl} 5 \mathrm{M}$. Pada penelitian ini diduga $\mathrm{HCl}$ mampu selain sebagai aktifan juga mampu membersihkan kerangka struktur mineral. Ion klorida akan menggantikan posisi $\mathrm{Ca}^{2+}, \mathrm{Na}^{+}$dan $\mathrm{K}+$ dalam ikatan ioniknya, sehingga nilai KTK yang diperoleh akan meningkat.

\section{Hasil uji adsorpsi terhadap limbah artifisial zat warna}

Data hasil pengujian setiap material zeolit yang diujicobakan terhadap limbah artifisial zat warna. Zat warna yang digunakan merupakan zat warna anionik yaitu zat warna reaktif. Zat warna reaktif yang digunakan adalah jenis Mono Chloro Triazin (MCT). Zat warna dibuat dengan konsentrasi 100 ppm, sedangkan zeolit yang digunakan sebanyak $50 \mathrm{~g} / \mathrm{L}$. Variasi yang dilakukan pada pengujian ini adalah melihat kemampuan adsorpsi dari zat warna reaktif pada berbagai rentang $\mathrm{pH}$ larutan. $\mathrm{pH}$ yang diamati meliputi $\mathrm{pH}$ asam, netral dan alkali. Larutan artifisial zat warna dikondisikan dalam berbagai variasi $\mathrm{pH}$ untuk kemudian diproses dengan zeolit alam yang sudah diaktivasi. Hasil uji tersebut dapat dilihat pada Tabel 5.

Tabel 5 menunjukkan bahwa penggunaan zeolit alam Gunung Kidul teraktivasi memberikan kinerja yang baik sebagai media adsorben untuk limbah artifisial zat warna tekstil pada kondisi aktivasi secara kimia pada $\mathrm{pH}$ asam. Hal ini menunjukkan bahwa proses aktifasi zeolit menggunakan asam lebih efektif untuk menghilangkan pengotor dalam zeolit baik organik maupun oksida logam.

Pada tahap dealuminasi, $\mathrm{HCl} 5 \mathrm{M}$ berfungsi untuk melarutkan oksida logam $\left(\mathrm{AlO}_{4}\right)^{5-}$ dengan membuka pori-pori zeolit menjadi berukuran pori lebih besar sehingga oksida alumunium dari kerangka dalam kristal akan keluar dan mendorong oksida alumunium keluar dari struktur zeolit dan terlarut dalam larutan $\mathrm{HCl} 5 \mathrm{M}$. Pengaruh $\mathrm{pH}$ terhadap proses adsorpsi menunjukkan bahwa kapasitas adsorpsi terhadap zat warna menurun dengan semakin tingginya $\mathrm{pH}$. Kapasitas adsorpsi pada $\mathrm{pH}$ asam lebih besar daripada $\mathrm{pH}$ basa. Tingginya proses adsorpsi pada $\mathrm{pH}$ asam dikarenakan meningkatnya protonasi oleh penetralan muatan negatif dari permukan adsorben. Sistem reaksi- difusi adalah konsentrasi dari satu atau lebih substansi terdistribusi dalam ruang berubah karena pengaruh dua proses yaitu reaksi kimia lokal dimana substansi diubah menjadi yang lain, dan difusi yang menyebabkan substansi menyebar dalam ruang.

Tabel 5. Efisiensi penurunan warna pada limbah artifisial dalam berbagai kondisi $\mathrm{pH}$ dengan beberapa jenis aktivasi zeolit alam

\begin{tabular}{lcc}
\hline \multicolumn{1}{c}{ Jenis Zeolit } & pH & $\begin{array}{c}\text { Efisiensi } \\
\text { Penurunan } \\
\text { Warna (\%) }\end{array}$ \\
\hline $\begin{array}{l}\text { Zeolit Alam } \\
\text { dengan }\end{array}$ & Asam (3) & 6,0356 \\
Aktivasi Fisika & & \\
$\begin{array}{l}\text { Zeolit Alam } \\
\text { dengan }\end{array}$ & & 75,9155 \\
Aktivasi Kimia & & \\
\hline $\begin{array}{l}\text { Zeolit Alam } \\
\text { dengan }\end{array}$ & Netral (7) & 3,9960 \\
Aktivasi Fisika & & \\
$\begin{array}{l}\text { Zeolit Alam } \\
\text { dengan }\end{array}$ & & \\
Aktivasi Kimia & & \\
\hline $\begin{array}{l}\text { Zeolit Alam } \\
\text { dengan }\end{array}$ & Basa (11) & 2,70510 \\
Aktivasi Fisika & & \\
$\begin{array}{l}\text { Zeolit Alam } \\
\text { dengan } \\
\text { Aktivasi Kimia }\end{array}$ & & \\
\hline
\end{tabular}

Adsorpsi maksimum larutan zat warna terjadi pada $\mathrm{pH} 3$ dimana terjadinya kesetimbangan antara zat warna dengan ion hidroksil didalam larutan, sehingga zat warna mampu menangkap ion hidroksil yang ditambahkan dan larutan zat warna akan mengalami penurunan kapasitas adsorpsi pada lebih tinggi. Jika dianalisa pada daerah $\mathrm{pH}$ netral kemungkinannya pada zat warna reaktif dapat terjadi oksidasi di permukaannya, sehingga dapat 
memberikan muatan positif ke permukaan zeolit. Pada $\mathrm{pH}$ rendah permukaan dari adsorben menjadi muatan positif dan akan terjadi serapan dari anion zat warna sehingga terjadi pertukaran adsorpsi. Selanjutnya pada $\mathrm{pH}$ basa terjadi penurunan kapasitas adsorpsi yang cukup drastis. dikarenakan $\mathrm{pH}$ basa dapat mengganggu peningkatan protonasi pada larutan zat warna. Hal ini dikarenakan ion $\mathrm{OH}-$ yang terlalu banyak dalam larutan tidak mampu ditangkap oleh zat warna, sehingga masih banyak ion $\mathrm{OH}$ - yang bebas didalam larutan yang menyebabkan terjadinya kompetisi antara zat warna dengan ion $\mathrm{OH}$ - bebas untuk menempati permukaan zeolit yang akan menurunkan daya adsorpsi zat warna dengan zeolit.

Hal lain juga dikarenakan $\mathrm{OH}-$ akan menetralkan larutan metilen biru sehingga kecenderungan muatan negatif pada adsorben tidak menarik adsorbat. Pada $\mathrm{pH}$ tinggi permukaan zat warna reaktif akan meningkatkan kation bermuatan positif melalui kekuatan elektrostatik tarik menarik. Meningkatnya kebasaan maka lapisan adsorben mengalami perubahan dari positif ke negatif, oleh karena itu dapat menurunkan kapasitas adsorpsi.

\section{KESIMPULAN}

Berdasarkan hasil pengujian dan percobaan yang telah dilakukan dapat dibuat beberapa kesimpulan:

1. Berdasarkan proses aktivasi terhadap zeolit alam Gunung Kidul proses aktivasi yang paling sesuai Zeolit asal Desa Sidomulyo Gunung Kidul adalah proses aktivasi kimia menggunakan asam. Perlakuan asam terhadap zeolit alam akan menghasilkan mineral jenis modernit yang cocok untuk digunakan sebagai media adsorben

2. Senyawa alumina dan silika merupakan komponen terbesar penyusun zeolit. Perlakuan asam memberikan rasio Si dan Al kecil yang menunjukkan bahwa kapasitas kationnya relatif besar.

3. Aktivasi secara kimia memberikan peningkatan volume dan luas permukaan yang diharapkan dapat meningkatkan kemampuan adsorpsi.

4. Perlakuan asam juga akan lebih meningkatkan sifat KTK dari zeolit alam Gunung Kidul.

5. Adsorpsi maksimum terhadap limbah artifisial zat warna diperoleh pada kondisi asam.

\section{PUSTAKA}

1. Saviano, M. \& Lourenco, F. R. Uncertainty evaluation for determining linezolid in injectable solution by UV spectrophotometry. Measurement. 46 (10), 3924-3928 (2013).

2. Liu, S., Zhao, N., and Rudenja, S. Surface Interpenetrating Networks of (Polyethylene terephthalate) and polyamides for Effective Biocidal Property. Macromol Chem Phys 21, 286-296 (2010).

3. Ambarwati, S., Adsorpsi Pewarna Naftol dengan Zeolit sebagai Adsorben, Skripsi, Jurdik Kimia, FMIPA, UNY. (2005).

4. Bukhori, Luqman, Budiyono, Aktivasi Zeolit dengan Menggunakan Perlakuan Asam dan Kalsinasi, Seminar Nasional teknik Kimia Indonesia (2003).

5. Emelda, L., Putri., S. M., Ginting, S., Pemanfaatan Zeolit Alam Teraktivasi untuk Adsorpsi Logam $\mathrm{Krom}\left(\mathrm{Cr}^{3+}\right)$. Jurnal Rekayasa Kimia dan Lingkungan Vol.9, No.4 hlm. 166 172 (2013).

6. Haryani, E., Kajian Adsorpsi Logam Cu (II) dan Zn (II) dengan Zeolit Alam Wonosari Gunung Kidul, Skripsi UIN Sunan Kalijaga (2015)

7. Kismolo, E., Nurimaniwathy, Suyatno, T., Optimasi Pemanfaatan Zeolit Alam dari Gunung Kidul untuk Reduksi Kadar Cesium dalam Limbah Radioaktif Cair. Prosiding Seminar Penelitian dan Pengelolaan Perangkat Nuklir. Yogyakarta (2008).

8. Laksono, E.W., Kajian penggunaan adsorben sebagai alternatif pengolahan limbah zat pewarna tekstil. Prosiding Seminar Nasional UNY (2009).

9. Lestari, D.Y., Kajian Modifikasi dan Karakterisasi Zeolit Alam dari Berbagai Negara. Prosiding Seminar Nasional Kimia dan Pendidikan Kimia. Jurusan Pendidikan Kimia UNY (2010).

10. Mazloomi, F., Jalali, M., Ammonium Removal from Aqueous Solutions by Natural Iranian Zeolite in the Presence of Organic Acids, Cations and Anions. Journal of Environmental Chemical Engineering (2015).

11. Millar, G. J., Winnet, A., Thompson,T., Couperthwaite, S.J., Equilibrium Studies of Ammonium Exchange with Australian Natural Zeolites.Journal of Water Process Engineering 9 47-57 (2016).

12. Nasihidiniyyah, Prasetyo, A., Kholifah, S. N., Kajian Adsorpsi Malasit Hijau pada Zeolit alam Termodifikasi. Seminar Nasional Green Technology 3. UIN Maliki Malang (2016).

13. Sutarti, M., Rachmawati, M., Pusat Dokumentasi dan Informasi Ilmu Pengetahuan Indonesia (LIPI). Jakarta (1994). 
14. Wahono, K.S. Pemanfaatan Zeolit Lokal Gunungkidul - Yogyakarta untuk Optimasi Sistem Biogas, Seminar Nasional Fundamental dan Aplikasi Teknik Kimia. Jurusan Teknik Kimia FTI-ITS (2008).
15. Wyantuti, S., Karakterisasi Zeolit Alam asal Cikalong Tasikmalaya, UNPAD (2008). 